\title{
BREEDING STATUS AND NOTES ON DIET OF THE NORTHERN SAW-WHET OWL AT DELTA MARSH, MANITOBA
}

TODD J. UNDERWOOD and SPENCER G. SEALY, Department of Zoology, University of Manitoba, Winnipeg, MB R3T 2N2; umunderw@cc.umanitoba.ca

Northern Saw-whet Owls breed in forests throughout southern Canada, northern and western United States, and some mountainous areas of Mexico. ${ }^{6}$ At Delta Marsh, Manitoba, saw-whet owls have been considered rare to uncommon from spring through fall. ${ }^{8,13}$ Recently, a mist-netting program run by the Delta Marsh Bird Observatory has shown them to be common fall migrants. ${ }^{10}$ We present observations that confirm breeding of saw-whet owls at Delta Marsh and identify prey items taken from pellets collected at a single roost site.

\section{Breeding Season Observations}

Data from the Prairie Nest Records Scheme indicate that saw-whet owl nests are active in Manitoba from March through July. Although the timing of pair formation is poorly known, ${ }^{6}$ breeding activity likely begins some time earlier than the first activity recorded at nests. Eight sightings of single adult saw-whet owls roosting have been recorded during or just prior to the breeding season at Delta Marsh: 22 February 1988 (K. A. Hobson), 27 April 1973 (E. E. Mowbray), 23 May 1999 (SGS), 24 or 25 May 2000 (SGS), 26 May 1992 (anonymous), 27 May 1985 (J. V. Briskie, K. A. Hobson, SGS), 5 June 1986 (J. V. Briskie), and 23 June 1982 (M. T. Sheridan). Some of these observations were made while TJU, SGS, and students conducted field research at the Delta Marsh Field Station (University of Manitoba) from 1974-2002.
Others were obtained from a logbook of observations at the field station and through personal communications with birders who visited the study area. In addition, two sawwhet owls were heard calling on 10 April 1995 during part of Manitoba's Nocturnal Owl Survey (J. Duncan pers. comm.). Two saw-whet owl specimens in The Manitoba Museum were collected at Delta Marsh: a female from 2 January 1971 (MM 2992) was possibly wintering and one of unknown sex found dead sometime in March 1949 (MM 2240) was a probable breeder.

A final record that suggests breeding in the Delta Marsh area was a juvenile sawwhet owl flushed on 16 July 1981 (SGS). Although this bird could fly, its presence at this time suggests fledging from a nest at or near Delta Marsh. On 19 July 1981, a juvenile, possibly the same bird, was captured in a mist net approximately $1.2 \mathrm{~km}$ west of where the individual had been flushed (SGS, H. E. den Haan pers. comm.).

The first nest for the area was found on 29 May 2000. On 15 May, TJU had found an adult saw-whet owl roosting in a shirub on the property of the Delta Waterfowl and Wetlands Research Station. Another adult or perhaps the same individual was spotted on 23 May about $1.5 \mathrm{~km}$ west of the first sighting. The owl at the second location remained for at least a day, but was gone on 26 May. On the morning of 28 May, 
presumably the same owl was roosting in a small spruce (Picea sp.) approximately 25 $m$ northwest of where it was seen on 23 May. This site was apparently a favored perch because on 29 May, 17 pellets were found on the ground beneath it and feces had begun to accumulate. Later that afternoon, TJU and Robyn Underwood located a large hole, roughly $8-9 \mathrm{~cm}$ in diameter, probably excavated by a Northern Flicker in a snag 6 $m$ north of the perched bird. Using a TreeTop Peeper $2^{\mathrm{TM}}$ nest inspection camera attached to an extendable pole, the cavity was examined that day and again on 31 May. At least five young saw-whet owls were observed in the cavity (Figure 1). The nest was $3.9 \mathrm{~m}$ high in a $4.2 \mathrm{~m}$ high snag that was approximately $50 \mathrm{~cm}$ in diameter at breast height. The nest was not visited again and the outcome of the breeding attempt was not determined.

Although saw-whet owls nest in various forested habitats, coniferous or mixed coniferous and deciduous forests appear to be preferred. ${ }^{6,16}$ The 15 saw-whet owl nests from Manitoba reported in the Prairie Nest Records Scheme were from areas described as or characterized by a mixture of spruce and aspen or poplar (Populus spp.) forest. Nests were located in Marchand, Whitemouth, Birds Hill Provincial Park, Grand Beach, and Riding Mountain National Park. Two other nest records from nest boxes located in southeastern Manitoba (Lonesand and McMunn) were also from mixed coniferous and deciduous forest ( $\mathrm{J}$. Duncan pers. comm.).

Breeding of saw-whet owls at Delta Marsh is interesting because of the habitat available. This area is characterized by a dune-ridge forest that separates the shore of Lake Manitoba from an extensive marsh $(\sim 15,000$ hectares) of open bays surrounded by cattails (Typha spp.) and reeds (Phragmites australis). ${ }^{17,18}$ The forest averages $80 \mathrm{~m}$ in width and is composed almost entirely of

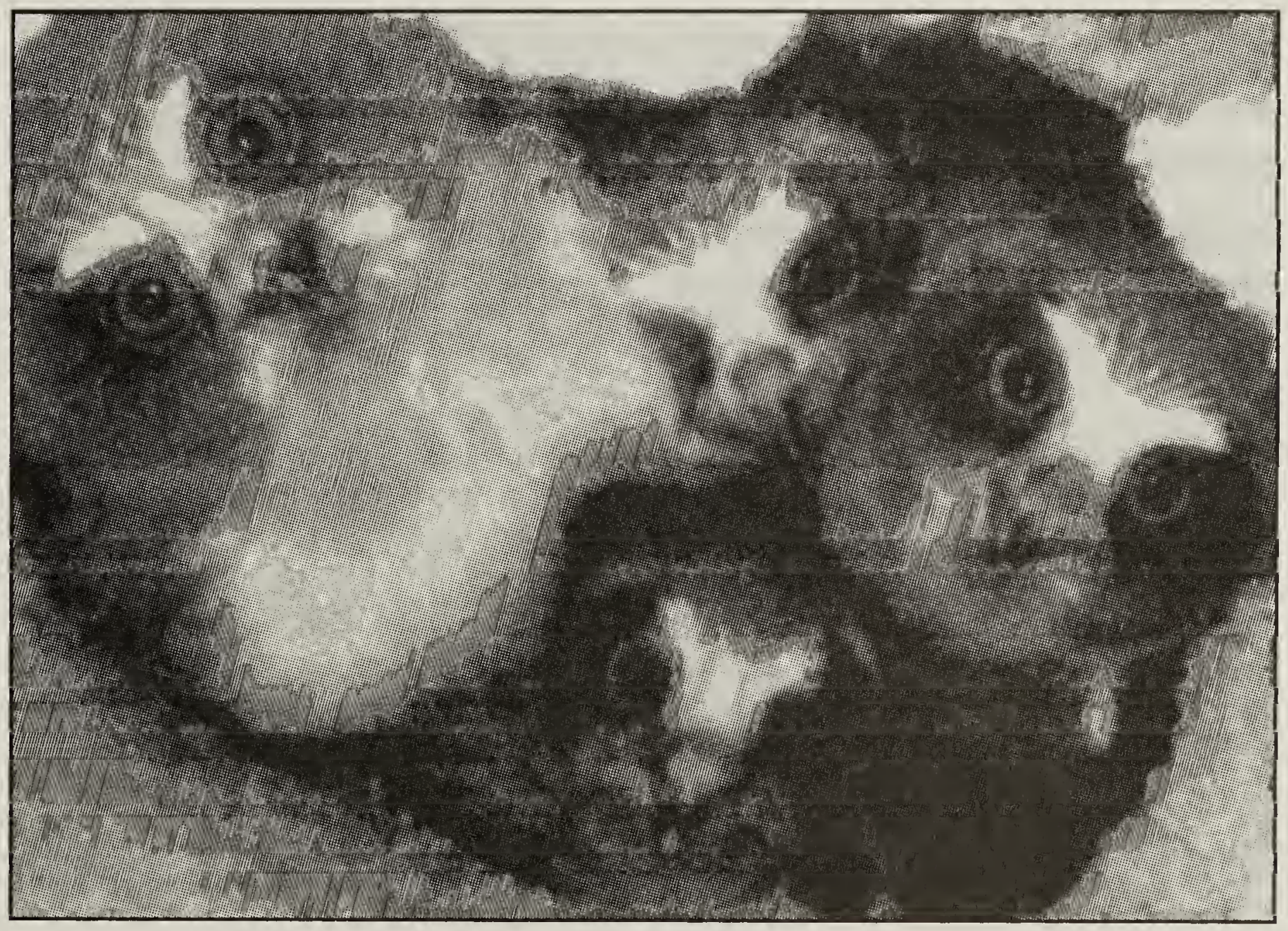

Figure 1. Northern Saw-whet Owl brood at Delta Marsh, Manitoba, 31 May 2000, from inside the nest. Image taken using a cavity nest inspection camera placed into the nest hole. 
deciduous trees and shrubs, such as Manitoba Maple (Acer negundo), Green Ash (Fraxinus pennsylvanica), Peach-leaved Willow (Salix amygdaloides), and Sandbar Willow (S. exigua). ${ }^{18}$ South of the marsh are small bluffs of Bur Oak (Quercus macrocarpa) and aspen along with agricultural fields and small patches of prairie. ${ }^{17}$ The few conifers present are mostly small ornamental spruces planted near cottages and houses. Delta Marsh is not, however, a unique breeding site. Sawwhet owls have nested in some riparian areas characterized by deciduous woods in British Columbia, ${ }^{5}$ Idaho, ${ }^{20}$ and Saskatchewan. ${ }^{1,4,22}$

\section{Diet}

The diet of saw-whet owls in the nonbreeding season has been well studied.6,7,12, 14, 23, 25 Mammals, especially deer mice (Peromyscus spp.) and voles (Microtus spp.), comprise more than $90 \%$ of the prey items taken, ${ }^{6}$ except for the subspecies (Aegolius acadicus brooksi) on the Queen Charlotte Islands, British Columbia, where marine invertebrates comprise about $50 \%$ of the diet. ${ }^{23}$ Only mammals were recorded in a report on the diet of saw-whet owls from Alberta. ${ }^{24}$ Deer Mice (P. maniculatus), Meadow Voles ( $M$. pennsylvanicus), Redbacked Voles (Clethrionomys gapperi), and shrews (Sorex spp.) were identified from pellets collected at various times of the year, although most were from "summer". ${ }^{24}$

Relatively little is known about saw-whet owl diet during the breeding season and most studies are from western North America. ${ }^{6,7}$ Mammals also comprise most of the diet, with birds accounting for less than $2 \%$ of the total prey items. ${ }^{5,15,20,21}$ Deer mice, voles, Pocket Mice (Perognathus parvus), Harvest Mice (Reithrodontomys megalotis), and House Mice (Mus musculus) are the most numerous prey items recorded. 5, 15, 20,21 Even less information is available on breeding season diet from the prairie provinces. In Alberta, unidentified rodents were observed being delivered to a brood. ${ }^{15}$ Several prey items also were found in two occupied nest boxes in southeastern Manitoba. A box from Lonesand contained three Meadow Voles, one Meadow Jumping Mouse (Zapus hudsonius), one American Redstart, and one unknown passerine nestling, whereas a box from McMunn contained a single Deer Mouse (J. Duncan pers. comm.).

At Delta Marsh, we collected 17 pellets on 29 May 2000 at a roost site near the active nest described above. Sixteen of these pellets averaged $27.6 \mathrm{~mm} \pm 1.4 \mathrm{SE}$ by 14.8 $\mathrm{mm} \pm 0.35 \mathrm{SE}$ (length by width) and $1.0 \mathrm{~g} \pm$ $0.08 \mathrm{SE}$ in mass. (The 17 th pellet broke apart before measurements could be made.) Dissection of the pellets revealed 14 prey items (Table 1). Not every pellet contained a single prey item, a few had mostly fur and only a few small bones. Saw-whet owls often cast two pellets for a single prey item eaten. $^{6,25}$ Mammal species were identified and numbers estimated by the sets of skulls and lower jaws. The number of birds was estimated by the number of mandibles. Most items were mammals but birds were common as well. Due to their relatively lower mass, the percentage of birds in the diet decreased by a third when diet was expressed on the basis of biomass (Table 1).

Of the nine mammals identified as prey, eight were Red-backed Voles and one was a Meadow Jumping Mouse. The only bird identified to species was a Least Flycatcher based on a band on its tarsus. This bird had been banded as an adult on 17 July 1998 by the Delta Marsh Bird Observatory and, thus, was approximately 3 years old (or older) in the spring of 2000 . The remains of four other birds were not identified because only the breastbones and portions of the skulls and lower mandibles were present. Based on size, we identified these as unknown passerines. In addition to prey from pellets, the adult owl observed on 23 May 1999 was holding the hind half of a jumping mouse (probably Z. hudsonius).

In contrast to other breeding or nonbreeding season studies, our data from Delta 
Marsh, albeit based on a small sample from a short time period, show a fairly high percentage of birds in the diet (Table 1). Other researchers have noted a consistent increase in the frequency of birds in the diet during the spring migration of songbirds. ${ }^{7,} 12$ This increase in songbirds may explain the high percentage of birds we found. Based on the production of one pellet per day, ${ }^{12}$ the 17 pellets collected were produced approximately between 12 and 28 May. These dates coincide with the peak songbird migration and the initiation of nests of several species at the study site.".

11 Delta Marsh is an important migration corridor and supports high densities of breeding songbirds. 3, 9, 11, 19 Thus, the breeding season diet of saw-whet owls at Delta Marsh likely reflects the high availability of songbirds, but more data are required to confirm this trend.

\section{Acknowledgments}

We thank Herb Copland, Heidi den Haan, Jim Fisher, and Keith Hobson for providing information, Jim Duncan for reviewing the manuscript and providing information, Janis Klapecki of The Manitoba Museum for providing access to the Prairie Nest Records Scheme and collections, Bob Nero for reviewing the manuscript, and Robyn Underwood for field assistance. Sealy's studies at Delta Marsh have been supported by the Natural Science and Engineering Research Council of Canada. We also thank Sandpiper Technologies, Inc. for loaning the nest inspection camera to TJU as a student equipment grant and the Delta Marsh Field

\section{Table 1. Analysis of 17 Pellets of the Northern Saw-whet Owl at Delta Marsh, Manitoba, Collected on 29 May 2000.}

$\begin{array}{lcccr}\text { Prey Items } & \text { Mean mass }(\mathrm{g}) & \text { Number } & \text { \% of total } & \text { \% biomas } \\ & & & & \\ \text { Red-backed Vole } & 16.7^{\mathrm{a}} & 8 & 57.1 & 66.4 \\ \text { Meadow Jumping Mouse } & 16.8^{\mathrm{a}} & 1 & 7.1 & 8.3 \\ & & 9 & 64.3 & 74.8 \\ \text { Subtotal } & & & & \\ & 10.8^{\mathrm{b}} & 1 & 7.1 & 5.4 \\ \text { Least Flycatcher } & 10.0^{\mathrm{b}} & 4 & 28.6 & 19.9 \\ \text { Unknown passerines } & & 5 & 35.7 & 25.2 \\ \text { Subtotal } & & 14 & 100.0 & 100.0 \\ \text { Total } & & & & \end{array}$

${ }^{a}$ Mammal masses were taken from specimens in The Manitoba Museum and the University of Manitoba Zoology Museum. The masses of pregnant or lactating females were excluded. Red-backed Vole masses ( $\mathrm{n}=34 ; 19$ males, 14 females) were from specimens collected at Delta Marsh and Winnipeg, Manitoba. Meadow Jumping Mouse masses ( $n=23 ; 12$ males, 11 females) were from specimens collected throughout Manitoba.

${ }^{b}$ Bird masses were obtained from birds mist-netted during 21-27 May in each of 1976 through 1983 at Delta Marsh. ${ }^{2}$ Least Flycatcher masses ( $n=102$, both sexes). For unknown passerines, Yellow Warbler mass was used $(n=178$, males) as a model small passerine because this species is the most abundant small songbird nesting at Delta Marsh. 
Station (University of Manitoba) for providing logistical support.

1. BELCHER, M. 1980. Birds of Regina, revised edition. Special publication No. 12, Saskatchewan Natural History Society, Regina.

2. BIERMANN, G. C., and S. G. SEALY. 1985. Seasonal dynamics of body mass of insectivorous passerines breeding on the forested dune ridge, Delta Marsh, Manitoba. Canadian Journal of Zoology 63:1675-1682.

3. BRISKIE, J. V. 1985. Growth and parental feeding of Least Flycatchers in relation to brood size, hatching order and prey availability. M.Sc. thesis, University of Manitoba.

4. CALliN, E. M. 1980. Birds of the Qu'Appelle, 1857-1979. Special publication No. 13, Saskatchewan Natural History Society, Regina.

5. CANNINGS, R. J. 1987. The breeding biology of Northern Saw-whet Owls in southern British Columbia. In: Nero, R. W., R. J. Clark, R. J. Knapton, and R. H. Hamre (eds.). Biology and Conservation of Northern Forest Owls: Symposium Proceedings. General Technical Report RM-142. USDA Forest Service, Rocky Mountain Forest and Range Experiment Station, Fort Collins, CO. p. 199-208.

6. CANNINGS, R. J. 1993. Northern Sawwhet Owl (Aegolius acadicus). In: Poole, A. and F. Gill (eds.). The Birds of North America, No. 42. The Academy of Natural Sciences, Philadelphia, PA and The American Ornithologists' Union, Washington, D.C.

7. CATLiNG, P. M. 1972. Food and pellet analysis studies of the Saw-whet Owl (Aegolius acadicus). Ontario Field Biologist 26:1-15.

8. CUTHBERT, C. W., and R. E. JONES. 1985. Birds of the Delta Marsh [check-list], second edition. Manitoba Natural Resources, Winnipeg.

9. DEN HAAN, H. 1997. Delta Marsh Bird Observatory interim report: 1997. University of Manitoba Field Station (Delta Marsh) Annual Report 32:23-26.

10. DEN HAAN, H. 2002. Northern Sawwhet Owl banding - 2001 report. Delta Marsh Bird Observatory, Delta Marsh, Manitoba.
11. GOOSSEN, J. P., and S. G. SEALY. 1982. Production of young in a dense nesting population of Yellow Warblers, Dendroica petechia, in Manitoba. Canadian FieldNaturalist 96:189-199.

12. GRABER, R. R. 1962. Food and oxygen consumption in three species of owls (Strigidae). Condor 64:473-487.

13. HOCHBAUM, P. W. 1971. The Delta Marsh. Manitoba Department of Mines, Resources and Environmental Management, Winnipeg.

14. HOLT, D. W., and L. A. LEROUX. 1996. Diets of Northern Pygmy-Owls and Northern Saw-whet Owls in west-central Montana. Wilson Bulletin 108:123-128.

15. JOHNS, S, A. JOHNS, and G. R. A. EBEL. 1978. Observations on the nesting behaviour of the Saw-whet Owl in Alberta. Blue Jay $36: 36-38$.

16. JOHNSGARD, P. A. 1988. North American Owls. Smithsonian Institution Press, Washington, D.C.

17. LÖVE, Á., and D. LÖVE. 1954. Vegetation of a prairie marsh. Bulletin of the Torrey Botanical Club 81:16-34.

18. MACKENZIE, D. I. 1982. The duneridge forest, Delta Marsh, Manitoba: overstory vegetation and soil patterns. Canadian FieldNaturalist 96:61-68.

19. MACKENZIE, D. I., S. G. SEALY, and G. D. SUTHERLAND 1982. Nest-site characteristics of the avian community in the dune-ridge forest, Delta Marsh, Manitoba: a multivariate analysis. Canadian Journal of Zoology 60:2212-2223.

20. MARKS, J. S., and J. H. DOREMUS. 1988. Breeding-season diet of Northern Saw-whet Owls in southwestern Idaho. Wilson Bulletin 100:690-694.

21. SANTEE, R., and W. GRANFIELD. 1939. Behavior of the Saw-whet Owl on its nesting grounds. Condor 41:3-9.

22. SEALY, S. G. 1965. Unusually large brood size of the Saw-whet Owl. Blue Jay 23:84. 
23. SEALY, S. G. 1999. Further data on food items of Northern Saw-whet Owls (Aegolius acadicus brooksi) on the Queen Charlotte Islands, British Columbia. Western Birds 30:200-205.
25. SWENGEL, S. R., and A. B. SWENGEL. 1992. Diet of Northern Saw-whet Owls in southern Wisconsin. Condor 94:707-711.

24. SMITH, H. C. 1976. Comparison of food items found in pellets of seven species of owls. Edmonton Naturalist 4(2):36-38.

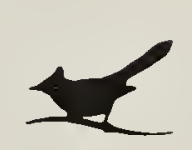

\title{
HABITAT FEATURES IMPORTANT TO BURROWING OWL BREEDING SUCCESS IN SASKATCHEWAN
}

\begin{abstract}
ROBERT G. WARNOCK and MARGARET A. SKEEL, Nature Saskatchewan, 206-1860 Lorne Street, Regina, SK S4P 2L7; warnockr@accesscomm.ca OR mskeel@naturesask.com
\end{abstract}

Burrowing Owls are unique among owls in that they nest in mammal burrows (usually ground squirrel or badger burrows in western Canada). They nest as solitary pairs or small loose colonies in open pastures with short grass, and also use taller grass-forb areas for hunting. 2, 8, 9, 22 The Burrowing Owl has been classified as an endangered species in Canada since 1995. ${ }^{24}$ The Saskatchewan owl population declined about 95 percent between 1987 and 2001, and the species range has been shrinking southward and westward since the 1940s (Nature Saskatchewan unpublished data). ${ }^{10,19}$ Habitat loss and fragmentation have been identified as the ultimate factors in the decline of the owl population in Saskatchewan.2, 21, 24 In 2000 , only 20 percent of former grasslands in Saskatchewan remained as natural habitat, and in highly arable areas it was as low as two percent. ${ }^{7}$ The Operation Burrowing Owl (OBO) program, delivered by Nature Saskatchewan, was launched in 1987 to protect grassland habitat for Burrowing Owls through voluntary landowner stewardship. ${ }^{19}$
Intensive studies of the Burrowing Owl in Saskatchewan since 1982 have looked at breeding biology and productivity, diet and foraging strategies, population dynamics, dispersal, migration mortality and postfledgling ecology. 2, 13, 18, 20, 21, 23 The only study of the relationships of habitat patterns and owl population dynamics across the owl's range in Saskatchewan examined population turnover but not breeding success. ${ }^{21}$ In 2000, the authors undertook a pilot study of habitat features that might be important to owl breeding success; this was conducted in conjunction with a program to visit all $\mathrm{OBO}$ members with nesting owls. The goal of the study was to determine whether habitat features play an important role in breeding success, and to identify those that would merit further study.

\section{Methods}

The study area included all known active OBO and Grasslands National Park (GNP) nest sites across the Burrowing Owl's current range in southern Saskatchewan (Figure 1). By early July, landowners, public land 